\title{
Vanessa Guignery and Christian Gutleben, eds., Traversée d'une cuvre: Crossing the River de Caryl Phillips
}

\section{Bénédicte Ledent}

\section{(2) OpenEdition} Journals

Electronic version

URL: https://journals.openedition.org/ces/4548

DOI: $10.4000 /$ ces. 4548

ISSN: 2534-6695

Publisher

SEPC (Société d'études des pays du Commonwealth)

\section{Printed version}

Date of publication: 1 September 2017

Number of pages: 159-160

ISSN: 2270-0633

\section{Electronic reference}

Bénédicte Ledent, "Vanessa Guignery and Christian Gutleben, eds., Traversée d'une œuvre : Crossing the River de Caryl Phillips", Commonwealth Essays and Studies [Online], 40.1 | 2017, Online since 02 April 2021, connection on 26 January 2022. URL: http://journals.openedition.org/ces/4548 ; DOI: https:// doi.org/10.4000/ces.4548

This text was automatically generated on 26 January 2022

\section{(ब) $\Theta$}

Commonwealth Essays and Studies is licensed under a Licence Creative Commons Attribution - Pas d'Utilisation Commerciale - Pas de Modification 4.0 International. 


\title{
Vanessa Guignery and Christian Gutleben, eds., Traversée d'une cuvre : Crossing the River de Caryl Phillips
}

\author{
Bénédicte Ledent
}

\section{REFERENCES}

Vanessa Guignery and Christian Gutleben, eds. Traversée d'une ceuvre : Crossing the River de Caryl Phillips. Cycnos 32.1, 2016. 231 p. ISBN: 978-2-343-10721-9. €24.50

1 This special issue of Cycnos is made up of twelve complementary essays that all focus on Caryl Phillips's Crossing the River (1993), a polyphonic novel that explores the history of the African diaspora and has now become a classic of Black Atlantic literature. In their solid introduction (in French), Vanessa Guignery and Christian Gutleben - the editors of the present volume and the organisers of the conference held in Lyon in October 2016 during which the contributions were first presented - provide the reader with a concise survey of Phillips's career as a prolific and multitalented British writer of Caribbean descent, give a synthetic yet enlightening overview of the various critical responses to his work and offer a summary of the articles gathered in the issue.

2 This edited collection is divided into four cohesive sections, in which the novel is read from different thematic or theoretical angles. "Échos, symétrie, renversement" comprises four textual readings of Crossing the River that concentrate on its structural and linguistic features and demonstrate how rewarding it is to pay close attention to the formal specificities of a text that in spite of its obvious choric dimension has sometimes been simply read for its content; the three essays in the second part, "Empathie, émotion, vulnérabilité," unpack the emotional power of Crossing the River, a facet which has been neglected because of the ambiguous and occasionally puzzling nature of this fiction; "Voix, corps, performance," the third section, contains three articles that focus on the novel's performative qualities, drawing attention to its 
mnemonic, musical and theatrical subtext; and finally, the two pieces in the last section, "Rapprochements théoriques," approach the novel through new interpretive lenses, in the context of queer theory, on the one hand, and as part of a rhizomatic discourse, on the other.

Taken as a whole, the diverse contributions convincingly bring to the fore the essential features of Crossing the River, and of Phillips's art in general, including the importance of the implicit dimension, the paradoxical tension between fragmentation and cohesion, and the fact that Phillips's texts rely on a complex web of resonances that the attentive reader is left to unravel. Among the most illuminating articles in the collection are those that undertake a close reading of Crossing the River, for example Christian Gutleben's exploration of the rhetorical and stylistic devices used by Phillips to deconstruct binarism and Catherine Lanone's examination of the epistemological implications of Phillips's use of repetition, whether linguistic or intertextual. Worthy of praise too are the pieces that deal with underexplored aspects of Phillips's novel, such as Kathie Birat's careful discussion of the notion of empathy and of how the "tension between knowing and feeling" (99) affects characters and readers alike, and Kerry-Jane Wallart's astute study of theatricality in Crossing the River, which not only highlights the importance of role-playing in Phillips's narratives but, by extension, also emphasizes the characters' physicality, which is a way of "retrieving a sense of humanity resisting exploitation" (186). One should also praise the conceptual power of some contributions, especially those written in French, which come up with interesting formulas capturing in a nutshell the spirit of Phillips's fiction, such as "poétique de la précarité" (Hubert Malfray) or "grammaire de l'exclusion" (Catherine Pesso-Miquel, 80).

Still, all the contributions do not fulfil their critical potential. Some of them remain superficial, tending to look more like informal papers than essays, even if they raise interesting issues and contain insightful close-readings that would nevertheless deserve more rigorous framing. This occasional impression of looseness might be due to the quick turnaround of this volume which came out only a few weeks after the conference that it memorialises. Another regret is the fact that the geographical and historical contexts of Crossing the River, notably Africa and slavery, are not tackled directly in the volume, while obliquely surfacing in most contributions, for example in Oriana Palusci's. The same could be said about the pervasive question of gender which is hardly discussed in the volume, except in Eleanor Byrne's essay, which reads Crossing the River, via James Baldwin, as a queer Black Atlantic text and foregrounds the intricate links between sexuality and race.

In spite of the imperfections mentioned above, which are somehow unavoidable in a collection of this kind, this volume will prove helpful to newcomers to Phillips's work while giving substantial food for thought to readers already familiar with his writing. Like the voices making up "the many-tongued chorus of the common memory" closing the novel, the interventions of the twelve contributors that resonate across the pages of this special issue will inevitably respond to each other and fruitfully dialogize with the ever growing body of criticism on Phillips's oeuvre. 


\section{AUTHORS}

\section{BÉNÉDICTE LEDENT}

Bénédicte LEDENT teaches at the University of Liège, Belgium, and is a member of the postcolonial research group CEREP (http://www.cerep.ulg.ac.be). She is the author of Caryl Phillips

(Manchester UP, 2002) and of articles on Caribbean and Black British literature. She has co-edited several volumes, among which Caryl Phillips: Writing in the Key of Life (Rodopi, 2012), with Daria Tunca. She is also co-editor of the Brill book series "Cross/Cultures: Readings in Post/Colonial Literatures and Cultures in English." 